\title{
The Emergence of Modern Humans
}

An Archaeological Perspective 



\section{The Emergence of Modern Humans}

An Archaeological Perspective

edited by

PAUL MELLARS 
(c) Edinburgh University Press 1990

22 George Square, Edinburgh

Transferred to Digital Print 2009

Set in Linotron Plantin

by Koinonia Ltd, Bury,

Printed and bound in Great Britain by

CPI Antony Rowe, Chippenham and Eastbourne

British Library Cataloguing

in publication data

The Emergence of modern humans.

1. Man. Evolution

I. Mellars, Paul

573.2

ISBN 0748601309 